\title{
Transmediating Tim Burton's Gotham City: Brand Convergence, Child Audiences, and Batman: The Animated Series
}

\author{
MATTHEW FREEMAN, University of Nottingham
}

\begin{abstract}
During the early 1990s, Batman, a highly valued media franchise, was an ever-expanding phenomenon, with franchise owner Warner Bros. having reinvigorated the property with Batman (Tim Burton, 1989). This article will examine the subsequent six-year period of its franchise production, using Batman as a case study for exploring the ways in which distinct versions of a fictional character - each constructed under different creative contexts with differing artistic sensibilities, aimed at varying groups of audiences across media - became the combined products of brand convergence across each media iteration, a concept that was crucial to the transmediality of Batman as both commercial brand and fictional storyworld.
\end{abstract}

\section{KEYWORDS}

Transmedia storytelling, media branding, franchise, merchandise, superhero characters.

\section{Introduction}

William Uricchio rightly acknowledges that 'Gotham City as a brand is a highly valued asset not only of the Batman franchise, but of the larger corporate entities of DC Comics and Warner Bros' (2010, 119). During the early 1990s, this Batman brand was an ever-expanding phenomenon, with franchise owner Warner Bros. having reinvigorated the property with Batman (Tim Burton, 1989). Batman Returns (Tim Burton, 1992), its sequel, was soon in development, and Warner Bros. would complement its theatrical release with a multitude of products in and across other media. Alongside the film was a series of video games, comic books and tie-in merchandise, each simultaneously promoting both Burton's blockbuster film and the character's latest television outing, Batman: The Animated Series (Warner Bros. Television, 1992-5).

This article examines this particular six-year period of Batman production history, exploring the ways in which distinct versions of the character - constructed under different creative contexts with differing artistic sensibilities, aimed at varying audience demographics across multiple media became the combined products of stylistic synchronicity across each media text, a concept crucial to the transmediality of Batman as both commercial brand and fictional storyworld. Stylistic synchronicity is a term coined for the purposes of this article that refers to the continued transmedial adoption of particular aesthetic or stylistic qualities that are not specific to any particular medium, but instead preserve a sense of textual unity and brand consistency between numerous texts across 
multiple media. Batman, as Roberta Pearson and William Uricchio suggested of the property in the early 1990s, posed 'seemingly endless re-articulations' with 'multiple narrativizations' of the 'the most divergent set of refractions' $(1991,164-5)$. The franchise had begun to witness different iterations of the character and his storyworld struggling for visibility and market share, each potentially 'threaten[ing] both the integrity of the commodity form and the coherence of the fans' lived experience of the character necessary to [its] continued success' (ibid., 184). Derek Johnson reasserts the importance of coherence in the building of a media brand, arguing that its sustained commercial success 'depend[s] on the [...] unity of texts' $(2007,85)$.

Positioning television's Batman: The Animated Series as the epicentre of this brand convergence, this article outlines how the various Gotham Cities of multiple media became incorporated, forming a coherent Batman storyworld that systematically fused elements of Golden Age comics with Tim Burton's gothic fairy-land film style, along with a 1940s 'dark deco' sensibility. In arguing that the Batman franchise of this era converged past and present iterations in ways that mediated audiences, I will highlight the role of television in facilitating these alternate versions into a form of brand convergence. This will involve engaging with mediation in terms of brand-building, pointing to the ways in which different systems of production - ranging from corporate branding to authorially specific means of transmedia - similarly melded together as extensions of a storyworld that expanded across media. This article thus situates itself within the interests of this issue in using branding to explain how a media franchise such as Batman during the early 1990s was employed to facilitate a complex mediation between different audiences of multiple Batman productions, with transmedia strategies being one facet of a marketing scheme designed to build Batman as a coherent brand.

\section{Convergence History}

It is therefore crucial to begin this article with a clear framing of each of these industrial practices, situating its argument inside the broader context of media convergence, itself 'the coming together of things that were previously separate' (Meikle and Young 2012,2). Convergence has come to dominate contemporary understandings of the models through which culture is produced industrially. Entire media industries, along with their technologies and practices, have become increasingly aligned, branded, and networked. As Henry Jenkins writes, 'media convergence makes the flow of content across multiple media inevitable' (2003). Convergence has accelerated the ways in which fictional creations are developed as media brands. Television, a medium founded upon the delivery of audiences to advertisers, is central to this acceleration. In turn, as Benjamin W. L. Derhy Kurtz notes in the introduction to this issue, 'the rise of transmedia platforms - offering the possibility to create websites, mobile games, alternative reality games, interactive exhibitions, ebooks, e-comics, webseries, and so on' has 'provided marketers with a whole new range of possibilities to boost both brand recognition and profits: rather than selling the show to networks, they now sell the story directly to consumers.' Transmedia has thereby become both a means and a source of understanding the flow of content and fictional storyworlds across media, with this flow initiating a slippage between practices of transmedia storytelling and media branding.

Transmedia storytelling has been defined as 'a process where integral elements of a fiction get dispersed systematically across multiple [media] channels for the purpose of creating a unified and coordinated entertainment experience' (Jenkins 2011). For Jenkins, this process of unfolding stories across multiple media platforms serves to make 'distinctive contributions to our understanding of the storyworld,' a fictional space that is constructed in and across these multiple media sources 
(2006, 334). World-making, then, itself the art of transmedia storytelling, argues Jenkins, is 'the process of designing a fictional universe that will sustain franchise development, one that is sufficiently detailed to enable many different stories to emerge but coherent enough so that each story feels like it fits with the others' $(2006,335)$. The precise industrial means through which this may occur has considerable overlap with concepts of branding, for to maintain brand recognition across a range of media texts and products itself requires a sense of textual or visual coherence across these products so as to ensure that each indeed feels like it fits with the others. In other words, whilst the concept of transmedia has become almost synonymous with recent digital transformations in the media landscape - often associated with new formats such as the webseries, for example - it is equally important to re-examine more traditional media whilst tracing the relationships between older industry media practices of licensing and merchandising and seemingly newer practices of transmedia. This approach yields a clearer grasp of branding as a trans-historical practice of media production that serves to bridge these older and newer practices together.

John Caldwell argues that 'branding has emerged as a central concern of the television industry in the age of digital convergence' $(2004,305)$. As Catherine Johnson continues, 'programmes are now being constructed as brands designed to encourage audience loyalty and engagement with the text beyond the act of television viewing' $(2012,1)$. Considerations of branding in this context work to evoke what Jenkins also calls brand extension, 'the idea that successful brands are built by exploiting multiple contacts between the brand and the consumer' (2006, 69). For Jenkins, this too 'should not be contained within a single media platform, but should extend across as many media as possible. Brand extension builds on audience interest in particular content to bring them into contact again and again with an associated brand' (ibid.). Following this logic, it is indeed crucial to emphasise the distinct slippage between concepts such as brand extension and transmedia storytelling, with the latter similarly conceptualised according to its extension of branded content across as many media as possible. Our ability to differentiate these concepts has typically relied upon the perceived demarcation of the latter's 'newness' in the contemporary context of digital media converges. Yet as I have examined elsewhere (Scolari, Bertetti and Freeman 2014), and as Jason Mittell asserts, 'any thoughtful study of contemporary transmedia must start with the vital caveat that transmedia is not a new phenomenon, born of the digital age' (2012-3). Rather than simply suggesting that new forms of transmedia storytelling have come to exist alongside older forms of licensing and merchandising - features that will be emphasised in this article - it is more useful to consider how transmedia storytelling operated during this specified era of the 1990s as an effect, rather than a preordained cause, of a company's brand-building configurations. Instead of understanding transmedia storytelling solely in terms of coherent storylines that unfold across multiple media, to what extent might we also understand the aesthetic coherence of the storyworld itself as that which facilitates a turn towards such transmedia phenomena? This complex slippage between strategies of media branding, which themselves would facilitate a branded convergence between multiple texts in different media, would, as we shall see, equate to what Jenkins has more recently termed world-making for the development of Batman's Gotham City in the early 1990s. In turn, this would encourage a form of transmedia storytelling to emerge - a form of transmedia based principally on the look of the branded storyworld rather than the plots of its adventures.

\section{The Burton Problem}

Before offering an examination of how transmedia emerged as a branding strategy for the development of the Batman franchise at this time, it is first necessary to offer an overview of the 
tensions and brand-splintering - its divergent set of refractions - established. 'Batman,' The New York Times wrote of Tim Burton's 1989 film blockbuster on July 1, 1990, 'remains an especially bold attempt to graft a dark, sweeping vision onto a comic-strip frame' (Maslin 1990). The newspaper argued, nonetheless, that 'Batman wound up going too far, as Anton Furst's majestically bleak production design ran away with the audience's interest, leaving behind the glum, moody would-be central figure of Batman [...]. However, Batman did demonstrably have something important: an ability to reach the mass audience' (ibid.).

The above description of Tim Burton's Batman represents a general reaction to the film upon its release. Critics typically admired the film's art design but mostly condemned 'its sour, cynical spirit and its taste for smirking sadism' (Maslin 1992). Roger Ebert asserted in his review: 'this is not a film for children - it is an extremely disturbing film' (1989). Given its dark, disturbing content, precisely how the film succeeded in reaching a mass audience was credit to Warner Bros.' expensive salesmanship techniques, exploiting a high-concept marketing strategy, selling the film as the event of the summer of 1989. The first Batman film brought in $\$ 251$ million in box-office receipts worldwide, with licensed merchandise - ranging from t-shirts to cereal - generating a further $\$ 500$ million in retail sales (Elliott 1992, 25). Such figures emphasise the extent to which Batman, as a brand, facilitated a move across products that was capable of generating far more income outside of the cinema than it was via the silver screen itself. All of which may have worked once, but could the trick be repeated for a second time? After all, the status of Batman as one of Hollywood's biggest commercial triumphs 'only compounded the sequel problem,' as The New York Times asserted on the day of the release of Batman Returns - 'creating pressure to re-activate this money machine at any cost' (Maslin 1992). Batman Returns was not quite the same 'event' as its predecessor, though this was a deliberate aspect of its marketing design. Robert G. Friedman, president of Warner's worldwide theatrical advertising, noted at the time of the film's release:

Unlike the first "Batman," we tried to keep the fires low and didn't start promoting it till relatively late. We focused on the individual characters that made up the whole of the movie, rather than trumpeting the movie as the event of the summer, like the first one. We opened it the first real weekend when kids were out of school. The audience is everybody, but the engine that drives the charge are kids under 20. (Weinraub 1992)

The intended audience of these two Batman films remains problematic. Friedman may have prioritised the under-20s in his presumed target audience for Batman Returns, but cinema at this time had begun to skew older. 'Although the main audience for movies remains under 25, the older crowd now represents an increasing share of moviegoers,' wrote The New York Times in 1995, estimating that 'the over-40 crowd represents 36 percent of moviegoers [...] in contrast to 23 percent in 1989' (Weinraub 1995, 18). In other words, the studios had been developing an increased number of adult-aimed films since the release of Batman in 1989. One year after its theatrical release, Batman premiered on $\mathrm{HBO}$ - a cable channel claiming an adult-orientated brand. The film even aired at 10pm, a timeslot catering towards an older audience (Zad 1990, 5). None of which is to suggest that Batman, in particular, was a cause of this broader shift, but it does provide at least some indication of why Warner Bros. had allowed director Tim Burton to develop 1992's Batman Returns as the dark, grotesque, adult picture it would become. Even so, Batman Returns was to be released in the summer, a period typically demarcated by film studios as the time of year in which 'all popcorn movies for the kids are played [...] while serious, adult movies go in the fall' (Weinraub 1995, 19).

This contradiction was also reflected in the film's marketing and promotional materials - 
components of its brand strategy. The character campaign, which included billboards and outdoor posters featuring the film's three primary characters - Batman (Michael Keaton), Catwoman (Michelle Pfeiffer), and the Penguin (Danny DeVito) - helped, according to Friedman, to 'aim the film at an older audience, which is more concerned with seeing interesting stories than younger moviegoers, who embrace a film as long as the action is great and the gadgets are there' (Elliott 1992, 26). The studio's lower-key approach was echoed in the company's ancillary licensing activities. 'We decided not to make a lot of noise,' said Dan Romanelli, president of Warner Bros. Consumer Products, 'and instead let the movie be the noise, and then come in on its own heels' (ibid.). This process saw Warner Bros. opening the film at different theatres across the nation on the Thursday night prior to its Friday opening, unleashing the film at 2,600 theatres on the Friday. Despite such strong claims for its lower-key marketing, Batman Returns was a highly marketed asset. The discrepancy, however, remains precisely who had intended to be the primary audience of this asset. Warner Bros., together with the studio's partners and merchandising licensees, were reported to have invested upward of $\$ 100$ million on marketing Batman Returns, much of which can be seen to demonstrate a broad, arguably contradictory branding agenda (ibid.). The film's merchandise ranged from Kenner toys for child boys to nightshirts and jackets for adult women. Immediately prior to the film's release on June 19, 1992, audiences watched tie-in commercials sponsored by Diet Coke, in which Batman and Catwoman duel over a can of Diet Coke, along with ads produced in connection with McDonald's and Choice Hotels, wherein the Penguin featured to promote a consumer sweepstake. Such marketing altogether reinforced Roger G. Friedman's aforementioned primary targeting towards 'kids under 20.'

However, this was all in addition to and in contrast with the film's theatrical trailers, which countering such overt commercialisation, emphasised the darker, Burton-esque elements of the film. These included scenes of the sewer-bound Penguin - who plots, according to the trailer's narrator, a 'foul reign of destruction' - along with fairly graphic scenes of violence such as the death of Selina Kyle (Catwoman's alter ego) and potentially frightening images of skulls and clown faces. One review described Burton's sequel as a 'dark, perverse and hugely expensive comedy' (Weinraub 1992, 13) - words hardly connoting the mainstream products typically affiliated with mass consumer brands such as Diet Coke and McDonald's. Batman Returns, as a product, demonstrated a tension of brand identities. The film's title character remained a hot property for children on account of his comic-book origins, yet director Tim Burton - having by this point found success with dark, off-kilter fairy-tales such as Beetlejuice (1988) and Edward Scissorhands (1990) brought with him his very own brand identity. Whilst not at the level of mainstream fame as Batman, Burton's brand did serve as a moderate commercial draw, albeit for a very different audience, one that did not necessarily overlap with the child audience most directly associated with the Batman image.

Newsweek's published review of the film, however, indicates a far more complex brand convergence between Burton and Batman:

If Batman was the darkest, weirdest, most unlikely blockbuster to slip out of the Hollywood corporate system, wait till you get a load of Batman Returns, this darker, weirder sequel [...]. Burton couldn't play it safe if he wanted to, and he doesn't want to. Entrusted with one of the most valuable franchises in movie history, he's made a moody, grotesque, perversely funny $\$ 50$ million art film. But like every other Burton oddity, from Pee-Wee's Big Adventure to Beetlejuice to Edward Scissorhands, it will probably be a big hit. Something about the filmmaker's eccentric, surreal, childlike images seems to strike a deep chord in the mass psyche: he makes nightmares that taste 
like candy. (Ansen 1992)

Newsweek's review hints at the extent to which Tim Burton's own branded visual style could serve as commercial appetite to a mass, even young, audience - and the filmmaker's vision for 'nightmares that taste like candy' would soon provide the core of the Batman character's transmedia brand convergence strategy upon its expansion to television. This expansion, crossing back and forth across media, will reveal how branding was employed to facilitate a complex mediation of audiences of multiple Batman productions, with transmedia one facet of a marketing scheme designed to build Batman as a coherent transmedia brand. This process will be returned to in the second part of the article, but for now and at this point in 1992, such dark, gothic sensibilities triggered mostly criticism, posing a firm problem for the franchise as a branded mass product. Another reviewer of Batman Returns warned:

The film includes enough trickery to attract children's attention. But a cartoonish spirit and a taste for toys do not make it a children's film. Parents should take into account the film's nightmarish setting, its characters' mean-spirited sparring and the fact that children are kidnapped and threatened with murder during the course of the story. (Maslin 1992, 28)

Indeed, a strong and notably angry response from many filmgoers followed in the immediate aftermath of the release of Batman Returns in the summer of 1992, many of whom despaired and were shocked over the film's violent images and were confused over its marketing as a summer blockbuster appropriate for children. Consider one audience member's response, whose letter, written to The New York Times, had condemned the newspaper for failing to acknowledge the 'ultra-realistic violence' of Batman Returns in its own published review:

At the screening I attended, the theater was full of children as young as 4 or 5 years old. As with the movie's predecessor, the marketing of the sequel clearly targets these children with as much gusto as it does teen-agers and adults. Were I a parent, and especially given the unreliable nature of the rating system of the Motion Picture Association of America, I might easily have taken my grade-school-aged child to see the film. I would have been outraged that no one in the press has had the sensitivity to warn me about the violence. (Lipsky 1992, 48)

Other audience letters echoed the sentiment: 'I just wish they'd make a Batman movie for kids,' one twelve year old complained, 'Because we really like Batman, and these movies aren't for us' (Britt $1992,2)$. The problematic tension that had arisen between Batman's longstanding child-friendly brand image and Tim Burton's newfound authorial status as a branded filmmaker with a 'cinematic fascination with freaks' had made for a string of angry headlines, and was tackled head-on in one article published inside The Washington Post:

So what bothered me about [Batman Returns]? Maybe it's the way director Tim Burton turns kiddie favorites such as rubber duckies, clowns and circus fire-eaters into destroyers. Batman himself is robotically ruthless, exploding and setting folks on fire. Maybe it's all the 'subtle' sexual stuff, like when Penguin leers at Catwoman, 'Just the pussy I was looking for!' Or Catwoman's sartorial choices: whips, leather, vinyl. Simply put, 'Batman Returns' is not a children's movie. 'How could that be?' you ask. Isn't McDonald's putting the hard sell on small kids - who else gets excited about 
Happy Meals and those tacky, plastic cups? Isn't every first-grade boy in the country dying to see it? (Britt 1992, 2)

Contrary to such strong public outcry, however, the film again proved to be a commercial success for Warner Bros. 'Batman has indeed returned,' announced The New York Times on June 22, 1992 (Weinraub 1992, 13). 'The newly opened sequel, "Batman Returns," broke box office records over the weekend and is poised to turn into one of the largest-grossing films ever' (ibid.). This report disclosed that, in spite of all the negative publicity deriving from the dark content of the film, Batman Returns had grossed 'a staggering \$46.5 million' during its opening weekend, a then record-breaking figure (ibid.). The previous record had been held by 1989's Batman, which had generated $\$ 42.7$ million during its first two days on release before going on to be become the sixth highest-grossing film in history at that point. Terry Semel, president of Warner Brothers Inc., noted at the time of the release of Batman Returns: 'It's clear that the chemistry in and around the movie the subject matter, the characters, the look of the film - appeals to children, to people in high school, to adults, male and female' (ibid.). That 'look' of the film, as had been described by the press with phrases such as 'German Expressionist design' (ibid.), 'Fascist sculpture' (Sharkey 1992, 16), '40s film noir' (Maslin 1990, 11) and 'Depression-era machine-age art' (Sharkey 1992, 16), was singled out for its 'bleakly futuristic' art design 'that will linger in the mind long after the actual story of "Batman Returns" becomes a blur' (Maslin 1992, 28). This style was at the centre of Tim Burton's brand identity that had brought both compliments for its 'eccentric, surreal, childlike images' (Ansen 1992) as well as criticism for its 'nightmarish, mean-spirited setting' 'that does not make for a children's film' (Britt 1992, 2). This look, then - created by Burton along with Anton Furst and Bo Welch, his production designers on Batman and Batman Returns respectively became the visual signifier of the Batman storyworld at this time, converging the sensibilities of both Burton and Batman into a single brand package that, despite its overt controversies, had proven successful. Expanding the franchise across other forms of media in a similarly coherent transmedia sensibility would thus require a delicate remodelled extension of this brand fusion, systematically diminishing - though not necessarily replacing - Burton's controversial brand of 'moody, grotesque' sensibilities so as to preserve what Derek Johnson describes as 'the unity and coherence' of Batman as a transmedia brand $(2007,85)$.

\section{Transmediating the Brand}

It was reported by The New York Times on July 3, 1995 that 'profit margins are running exceedingly thin throughout the movie industry, while several leading companies - particularly Warner Brothers' parent [and Batman franchise owner] Time Warner Inc. - are carrying heavy debt' (Fabrikant 1995, 37). Accordingly, the major Hollywood studios of the early to mid-1990s had placed more emphasis than ever before on the sales of big-budget franchise properties, each developed according to 'brand-name recognition' (ibid.). None had more brand-name recognition at this particular time than Batman, with many of the top executives at Warner Bros. often speaking of the character as 'the company's largest asset' (Maslin 1995, 16).

On account of factors such as these, along with much broader industrial developments that had been taking place since the $1980 \mathrm{~s}$ - including increased configurations towards media convergences and the rising dominance of conglomerate production practices such as synergy - Warner Bros.' approach to the development of Batman aligned with its development as a branded transmedia product. Individuals such as Nick Shore and Paul Bennett, advertisers who worked in partnership with Warner Bros. in order to develop the studio's marketing and licensing strategy for its output 
including, most notably, Batman Forever (Joel Schumacher, 1995), epitomised this period's corporatised approach to the increased significance amongst media properties of 'brand wrangling' (Elliott 1995, 6). The duo offered Warner Bros. strategic and creative expertise on how to 'start, sustain and strengthen brands' (ibid.). 'If you design a brand from scratch, or redesign one,' insisted Stone of the Batman franchise in 1995, 'you need a multidisciplinary understanding of its essence, what it's all about, how it's perceived. What are the genetics of this brand? What is its DNA?' (ibid.). Shore and Bennett were indicative of how marketing communications concerning intellectual properties such as Batman were being further reconfigured as film studios - and advertisers - strove to keep their movie products in constant public view amongst an increasingly crowded marketplace. 'The title we give to what we do is brand design,' Shore asserted, 'which unites advertising, packaging, promotion, event, marketing, public relations and other sales tactics in a cohesive whole' (ibid.). Bennett asserted of the previous marketing approach taken for Batman Returns: 'We told [Warner Bros.], "You're spending a gazillion dollars on advertising but your package says something different." Consumers are confused enough without mixed messages' (ibid.).

Batman: The Animated Series, then, serves as a case study for examining the ways in which a media property such as Batman was both diverged and converged at this time into a steadily unified and transmediated entertainment phenomenon, a textual embodiment of this period's packaging of media brands in ways that promoted the dispersion of intellectual property across a corporation as transmedia extensions without confusing consumers. The series - produced by Warner Bros. Animation and broadcast on Fox Kids Network between September 5, 1992 and September 15, 1995 - aired on weekday afternoons around 4:30pm. It was intended to capitalise on the appetite for Batman amongst younger children, as had been demonstrated by the huge merchandise sales that accompanied both Batman and even, though to a much lesser extent, Batman Returns. The problem facing Warner Bros. was accordingly one of branding: the television series would need to package itself as catering most pointedly to a child demographic whilst all the while not compromising the adult inflection of Burton's films, which had itself become part of the genetics of the Batman brand, part of its DNA. In a way comparable to the branding issues faced by Tim Burton during the making and reception of his own films, the production of Batman: The Animated Series would provide similarly contradictory problems for Warner Bros.' ongoing battle to mount a coherent brand out of its largest asset. There would even be similar questions raised over its apparent appropriateness for the eyes of children. When addressing the struggles he had faced with censors, Bruce Timm, a producer on the series, asserted: 'We were just like, "Look, we're not trying to destroy the boys of America. We just want to make a good show.' (2004a) Timm would address this problem of differentiating the brand as well as broader issues to do with divergence versus convergence in interview, noting:

Right off the bat we wanted to make a statement. We wanted to say right away that this was not any other version of Batman you've ever seen; it's not the Adam West version [and] it's not Tim Burton's version. It was our Batman (ibid.).

However, and in spite of the producer's insistence on the uniqueness of this version of the character, Timm would also acknowledge the heavy role of borrowing and building upon the styles and sensibilities of earlier versions - including, particularly, Burton's Batman. Batman: The Animated Series represented 'what we considered to be the best of Batman,' he later teased, 'We drew from those different sources - from the comics, from Adam West, and from the [Burton] movies - but we tried to do a distillation of what we felt was really important about Batman' (ibid.). That importance, according to Timm, overlapped considerably with that which had been foregrounded 
already in Tim Burton's works, with the television series quite similarly opting to 'focus on mood, mystery, [and] atmosphere' (ibid.). In perhaps the most telling and concise summation of the intended tone of Batman: The Animated Series, Timm described the text as 'essentially adult without being gratuitous. It's not adult in a sexy or violent way, but it's a very sophisticated, grownup story' (2004b).

Two things were being addressed here. First, Timm's comments hint at the negative audience feedback that followed Batman Returns, with 'gratuitous' 'sexy violence' echoing the criticisms of Burton's film, cited above, as being 'not for children' and 'sexual' and 'too violent.' Second, these same comments also served paradoxically to reinforce the apparent commercial appetite for Tim Burton's 'nightmares that taste like candy' - thus at once distancing his own production from Burton's works whilst simultaneously acknowledging a direct, borderline transmedial overlap with these works by emphasising its 'sophisticated, grown-up' design. Batman as a visually dark, noirish creation had become part of the artistic fabric of Batman as a brand, and as such it needed to remain part of its textual fabric. Any drastic alterations to the visual style of Batman at this stage may have splintered its brand image, 'threaten[ing] both the integrity of the commodity form and the coherence of the fans' lived experience of the character necessary to [its] continued success' (Pearson and Uricchio 1991, 184).

The role of the look and the visuals of a media brand were thus strikingly centralised, with these aspects demonstrating how brand convergence could function to develop a storyworld transmedially. Jenkins, in particular, has more recently recognised the role of preserving such stylistic synchronisation between branded media products, though he prefers to understand the concept as part of the transmedia process of world-making. According to Jenkins, for transmedia storytelling - itself, Jenkins argues, the art of world-making - to work efficiently, the storyworld on display needs 'sufficient consistency that each instalment is recognizably part of the whole and with enough flexibility that it can be rendered in all of these different styles of representation' (2006, 115). As Jenkins notes of The Matrix world:

Across those various manifestations of the franchise, there are dozens of recurring motifs, such as falling green kanji, Morpheus' bald head and mirror-shade glasses, the insectlike ships, Neo's hand gestures, or Trinity's acrobatics. No given work will reproduce every element, but each must use enough that we recognize at a glance that these works belong to the same fictional realm. $(2006,115-116)$

Similarly, the branded Gotham City on display in the many Batman productions of this era is mostly a stylistically synchronised storyworld, a dark space based on the eclectic stylisation of Burton's Gotham. As cited already, this Gotham City had been branded a '40s film noir', evocative of 'German Expressionism.' As with the transmediated storyworld of The Matrix, there are visual motifs in Batman: The Animated Series that enabled audiences to recognise that this particular version of Gotham belonged to the same fictional realm as Burton's Gotham - cross-promoting each text as one component of a much larger transmedia narrative. Most pointedly, the series had been seen to embody a similar 'otherworldly timelessness' that epitomised the films. Note one reviewer's response to the series, whose suggestion that it 'was like if the 40s had been moved up to modern day, then pushed into a bucket of black paint' (Elliott 1995, 6), echoes the characterization of the Burton world by Danny Elfman, composer on Batman and Batman Returns, as a 'noir nightmare [that] could have been from 1942' ('Batman's Back', 1989). This review of Batman: The Animated Series continued: 'The film-noir aspect helped paint Gotham City as a bustling metropolis 
by day, and a dark, dirty, devilish place by night' (ibid.). The non-linear narratives also served to evoke this Burton-esque film noir sensibility on a structural level. Characters including the Penguin were modelled on Burton's live-action counterparts. This stylistic synchronisation was further afforded through music, with Danny Elfman's score also applied to the opening sequence of the television series. Shirley Walker, the series' composer, sought to emulate Elfman's theme. The music became an additional means of synchronising cinema's Batman and Batman Returns with television's Batman: The Animated Series as components of a cohesive transmedia whole. The theme became part of how Batman was constructed both in and across media, meaning that its subsequent reappearance on television functioned as a stylistic motif that connected each of these Batman productions together as correlated affiliations of a single brand property. Another review of the series surmised the production according to such brand mediation, hailing the television series as 'a perfect medium between all the worlds of Batman. The Adam West series is corny; the Tim Burton films are dark, and Batman: The Animated Series is a mixture of dark realism and action for the kids' (Salas 2010).

We can hereby begin to comprehend this era's entire slate of Batman productions according to their status as brand convergences - the violent extremes of one text mediated with the lightness of another in a way that preserved the franchise's overall brand coherence, encouraging transmedia affiliations between the numerous texts to develop as a result. Bruce Timm, producer of Batman: The Animated Series, may have initially sought to differentiate his production from the Tim Burton films, yet we have already seen the extent to which the series offered an extension of that storyworld. The series spawned a range of merchandise, all of which was produced as toys aimed at the child market. This particular range proved even more popular amongst children than the Kenner toys accompanying Burton's Batman films, itself a strong indication of the extent to which Batman: The Animated Series had already mediated the dark/light dichotomous brand image of Batman. Soon the series would expand back to cinema, with Warner Bros. developing a new animated feature film produced by the team of the television series. Batman: Mask of the Phantasm (Eric Radomski and Bruce Timm), released on Christmas Day 1993, suggests the extent to which Warner Bros. had all the while sought to emulate the box-office popularity of the Burton films in spite of the critical and audience controversy surrounding their violence, thereby extending the branded image of those films' dark storyworld across cinema, television, and back again to the cinema. With regards to the return to the violence of the Burton era, for instance, one review claimed: "Batman: Mask of the Phantasm" is the strangest PG film of the year. Though drawn from the popular animated series, the movie is not bound by TV's restraints, which may surprise some parents with its violence' (Harrington 1993, 7). Moreover, Batman: Mask of the Phantasm was sold as that which narrated the origin of Batman - a series of events not told in either Tim Burton's Batman or its sequel - in a way which therefore allows us to comprehend this film in terms of transmedia storytelling. This animated film, after all, unfolded its flashback-formed narrative in ways which narrated the tale of Batman's origins in multiple productions across multiple media: 'Set in the 1940s,' one review remarked, "Mask of the Phantasm" is a cartoon film noir evocation of events that purport to explain the origins of Batman' (Holden 1992, 21). Indeed, the film adopted the television series' film noir aesthetic, itself developed from the style of the Burton films. Other review materials indicate the extent to which the film had been promoted - and indeed received - as a coherently transmedial extension of this Burton-inflected Gotham City:

Overall, the film is stylishly dark in the manner of the Tim Burton "Batman" films. Even the story here seems more adult-orientated then the animated series' action-plots (and since much of it is told in flashbacks, it may also be confusing to younger filmgoers) [...] The film looks good on the big screen, very Burtonesque from a long 
opening-credit journey through Gotham's dark architecture, to the Gothic/deco shapes and angles. (Harrington 1993, 7)

The television series' own strategies of brand convergence had thereby further facilitated the Batman franchise's sustained world-making across multiple media, in turn even permitting particular instances of transmedia storytelling. The fused if eclectic visual sensibility of the Batman storyworld operated as synonymous with both the commercial agenda of its brand-building and the artistic agenda of its principal character's story as a transmedia development. For our purposes, it indeed becomes most useful to comprehend these attributes of stylistic synchronisation, or worldmaking, as an industry practice of media branding that in turn only encouraged the transmediated consumption of a storyworld, with the adoption of these aforementioned aesthetic sensibilities in the Batman television series indicating that Warner Bros. had wished to preserve a strong stylistic synchronisation across each of the era's Batman media components. In doing so, it becomes feasible to understand the practices of branding, along with marketing, licensing and merchandising - each considered throughout this article - collectively as altogether embodying and indeed representing a slightly older model of transmedia production, one emerging amidst the industrial contexts of this period.

Such industrial contexts included the role of regulation on television. Batman: The Animated Series, for instance, had represented a subtle and complex mediation of brand identities - shrewdly skewing the oft-controversial, though commercially successful, style of Burton's films with a production that both extended a coherent embodiment of this storyworld whilst directly targeting the child audience, thereby constructing a unified brand identity out of the controversial violent remains of the Batman pictures. Yet its status as a children's television programme - broadcast into the living rooms of homes via Fox Kids Network - had meant a more censored production than had been inflicted upon Burton's PG-13-stretching features. Whilst preserving a relatively consistent, transmediated visual look to the series, Batman: The Animated Series' necessary compliance with the regulations of the Children's Television Act of 1990 - a movement founded upon 'broadcasters' public interest responsibility to meet the educational and informational needs of children' - denied any depiction of murder (Ness 1995, 24). Villains could therefore not be seen killing in the series, a tonal shift that whilst in contrast to the violent depictions of murder in Burton's films, would, as we shall now see, permeate into the brand strategy of Batman Forever (Joel Schumacher, 1995), a film whose antagonist insists at one point: 'Don't kill [Batman]! If you kill him, he won't learn nothin.'

Indeed, Batman Forever, released theatrically on June 16, 1995, replaced the 'offbeat casting' of Michael Keaton with the 'more handsome Val Kilmer' (Hinson 1995,17), all the while employing 'Joel Schumacher's flashy, messy, less interestingly macabre direction [over] Tim Burton's darkly ingenious films in this genre' (Maslin 1995, 16). Batman Forever was the highest grossing of these three Batman films, "pull[ing] in $\$ 52.7$ million in ticket sales during its opening weekend [...] the biggest opening weekend ever for a movie' at that time (Farhi 1995, 2). The film's $\$ 30$ million licensing budget replaced deals on Batman Returns to produce Catwoman nightgowns aimed at adults with items that included Batman-branded toddler pyjamas and toys such as those based on the Riddler's question-mark-shaped walking stick, each targeting a younger consumer than the franchise had ascertained only three years earlier (Fabrikant 1995, 37). 'Gotham City is now a few shades brighter and less forbidding, as befits the Happy Meal ambitions of "Batman Forever,", highlighted The New York Times (Maslin 1995, 16). 'Clean language and comic book violence of the THWACK! BOOM! variety makes this three-quel okay for most kids aged 10,' reassured The 
Washington Post (Horwitz 1995, 7). As another Washington Post-published review also commented of Batman Forever, 'with its cleaner narrative lines, its jokey tone and its more conventional new leading man, "Batman Forever" is probably a lot closer to what most people expected when Warner Bros. began adapting the comic book to the screen with "Batman" in 1989' (Hinson 1995, 17).

Batman Forever had represented one extreme in the franchise's complex brand development process. This particular product embodied the light in contrast to the darkness of the Burton films, with television's Batman: The Animated Series and its accompanying Batman: Mask of the Phantasm deliberately mediating both sets of extremes into a flowing, gradually unfolding, transmediated brand package. This film may have sacrificed critical acclaim - one reviewer deemed it 'an empty-calorie equivalent of a Happy Meal [...] so clearly a product that the question of its cinematic merit is strictly an afterthought' (Maslin 1995, 16) - but Warner Bros.' complex, troubled (re)building of Batman into a coherent brand asset, filtered fluently across a range of media forms and merchandising outlets, each targeting cornerstones of an all-encompassing mass consumer, from dark to light, old to young, was complete.

\section{Conclusion}

Much of this article has documented the tensions that arose between a media company and its audiences on account of the former's struggle to construct a coherent brand identity out of its largest asset. Batman, an intellectual property whose filtering through the hands of a notably successful film director with his own particularly well-defined brand identity, had drawn both commercial success and critical revolt against the perceived 'lack of Batman in Batman' (Maslin 1990, 11). I have hereby attempted to outline the ways in which Warner Bros. developed its Batman franchise according to a model of brand extension, both diluting and preserving the controversial underpinnings of Tim Burton's creation across media, thereby building a coherent (trans)media brand that only subtly transformed from the dark, grotesque visions of Batman and Batman Returns into the light, frothy adventure of Batman Forever. Those tensions arose predominantly out of a film culture in the early 1990s that had become accustomed to watching more adult-orientated product, with Warner Bros. steadily aware of the need to market a brand product such as Batman to a truly mass audience in ways that did not sacrifice one particular market over another. Perhaps accordingly, and as one reporter aptly concluded of the undeniable if unaccountable commercial success that greeted those earlier films, "with a dark visionary like director Tim Burton at the helm, "Batman" and 1992's "Batman Returns" managed to become blockbusters almost in spite of themselves' (Hinson 1995, 17-18). Developing this dark vision of Batman as a coherent brand image, one that unfolded and expanded across media and merchandise, continuing to attract - rather than to alienate - the character's built-in child audience had required a process of brand mediation fraught with tensions, complications, compromises, and battles between censors, networks, writers, and marketers. 'Burton-esque' had become ingrained into the textual fabric of the Batman brand, defining its storyworld as a recognisable entity. Extending that brand entity had meant simultaneously preserving the controversially dark sensibility of Tim Burton in all subsequent Batman texts whilst finely diminishing his presence across further iterations.

Indeed, by ensuring that the storyworld of Gotham City remained stylistically synchronised and tonally consistent across multiple media, Warner Bros. had developed their branded franchise into a thriving transmedia product. It was a development that had been afforded, particularly, through the medium of television, an increasingly centralised media hub for the branded consumer messages of convergence culture. Amidst broader industrial developments towards the convergences of media 
platforms as commodified outlets, the transposition of Batman, albeit temporarily, to television can be understood as a response to these industrial transformations. Television, as a mass medium broadcast directly into audience's homes, had served as a solution to the risk of potentially splintering the Batman brand amidst multiple narrativisations. Batman, as a brand, as a franchise, or as a fictional storyworld that cut across a multitude of media channels, acted as a site through which diverse audiences and differing authorial contexts subsequently converged as components of a branded transmedia product.

\section{References}

Ansen, D. (1992) 'A Gothic Gotham', Newsweek, 21 June. Accessible at http://www.thedailybeast.com/newsweek/1992/06/21/a-gotham-gothic.html. Accessed on 2 September 2013

'Batman's Back' (1989), Summer of Batman 1989, [video]. Accessible at http://www.youtube.com/watch?v=MgKd4EBzcqY. Accessed 12 September 2013

Britt, D. (1992) 'As “Batman Returns,” Parents Cringe Again', The Washington Post, 19 June 19, 2 Caldwell, J. T. (2004) 'Branding' In: Newcomb, H. (eds.) Encyclopaedia of Television: Volume 1, New York: Fitzroy Dearborn

Ebert, R. 'Siskel \& Ebert Batman (1989) Review', Siskel \& Ebert At The Movies, [video]. Accessible at http://www.youtube.com/watch?v=nZ3taEufae0. Accessed 12 September 2013

Elliott, S. (1992) 'Batman Returns, but Brings Far Fewer T-Shirts,' New York Times, June 9: 25-26 --- (1995) 'Advertising,' New York Times, September 22: 6

Fabrikant, G. (1995) 'Why Studios Bet on the Summer Blockbuster', New York Times, 3 July 3, 37 Farhi, P. (1995) 'Holy 52-Week High, Batman!' The Washington Post, 20 June 20, 2 Harrington, R. (1993) 'The Very Dark Side of "Batman”, The Washington Post, 27 December, 7 Hinson, H. (1995) ““Batman”: The Riddler Forever?', The Washington Post, 16 June, 17-18

Holden, S. (1992) 'The Caped Crusader Returns, in 40s Noir Mode', New York Times, 28 December, 21

Horwitz, J. (1995) “"Batman': Not Much Bang in the 'Pow!'”, The Washington Post, 22 June, 7

Jenkins, H. (2003) 'Transmedia Storytelling.' Technology Review. Accessible at http://www.technologyreview.com/news/401760/transmedia-storytelling/. Accessed 4 February 2013

--- (2006) Convergence Culture: Where Old and New Media Collide. New York: New York University Press

--- (2011) 'Transmedia 202: Further Reflections,' Confessions of an Aca-Fan, August 1. Available at: http://henryjenkins.org/2011/08/defining_transmedia_further_re.html. Accessed 28 August 2013 Johnson, C. (2012) Branding Television. London: Routledge

Johnson, D. (2007) 'Will the Real Wolverine Please Stand Up? Marvel's Mutation from Monthlies 
to Movies', in I. Gordon, M. Jancovich and M. McAllister (eds.), Film and Comic Books, USA: University Press of Mississippi, pp. 64-85

Lipsky, M. (1992) 'Batman Returns: Violence, too, is Socially Relevant', New York Times, 12 July, 48

Maslin, J. (1990) 'Comics Heroes are Dwarfed by Movies', New York Times, 1 July, 11

--- (1992) 'A Sincere Bat, a Sexy Cat and Bad Bird', New York Times, 19 June 19, 28

--- (1995) 'New Challenges for the Caped Crusader', New York Times, 16 June, 16

Meikle, G. and Young, S. (2012) Media Convergence: Networked Digital Media in Everyday Life, London: Palgrave Macmillan

Mittell, J. (2012-3) Complex TV: The Poetics of Contemporary Television Storytelling, prepublication edition (MediaCommons Press). Accessible at

http://mediacommons.futureofthebook.org/mcpress/complextelevision/transmedia-storytelling/.

Accessed 4 September 2013

Murray, S, (2005) 'Brand Loyalties: Rethinking Content Within Global Media', Media, Culture and Society, 27(3), 415-35

Ness, S. (1995) 'Responsible TV', The Washington Post, 27 October, 24

Pearson, R. and Uricchio, W. (1991) The Many Lives of the Batman: Critical Approaches to a Superhero and his Media, New York: Routledge

Salas, Z. (2010) 'Batman: The Animated Series', Thomas Jefferson Journal, 25 February. Accessible at http://www.tjjournal.com/2010/02/25/batman-the-animated-series/. Accessed 1 September 2013

Scolari, C. A., Bertetti, P., and Freeman, M. (2014) Transmedia Archaeology: Storytelling in the Borderlines of Science Fiction, Comics and Pulp Magazines, London: Palgrave Pivot

Sharkey, B. (1992) 'Batman's City gets a New Dose of Urban Blight', New York Times, 14 June, 16 Timm, B. (2004a) 'On Leather Wings: Commentary', Batman: The Animated Series: Volume 1 The Legends Begins, [DVD], Warner Home Video, ASIN: B0001XLY24

--- (2004b) 'Two-Face: Part One: Commentary', Batman: The Animated Series: Volume 3 - Out Of The Shadows, [DVD], Warner Home Video, ASIN: B0007CTKNY

Uricchio, W. (2010) 'The Batman's Gotham City'T: Story, Ideology, Performance', in J. Ahrens and A. Meteling (eds.), Comics and the City: Urban Space in Print, Picture and Sequence, New York: The Continuum International Publishing Group Inc., pp. 119-32

Weinraub, B. (1992) 'Batman is Back, and the Money is Pouring In', New York Times, 22 June, 13 --- (1995) 'And Now, Something for the Grown-ups', New York Times, 14 May, 18-19

Zad, M. (1990) “"Batman” Drives Batmobile 25 Times on HBO and Cinemax', The Washington Post, 8 July, 5 